\title{
Harmonisasi dan Sinkronisasi Hukum terhadap Perbedaan Pengaturan Barang Impor dalam Keadaan Baru
}

\author{
Leny Pratiwi \\ Fakultas Hukum Universitas Atma Jaya Yogyakarta \\ Jln. Mrican Baru 28, Yogyakarta \\ pratiwileny@ymail.com
}

Received: 14 Januari 2018; Accepted: 27 Mei 2018; Published: 14 Agustus 2018

DOI: 10.20885/iustum.vol25.iss1.art4

\begin{abstract}
The objectives of this study were to determine and examine the factors causing differences in the regulation of imported goods in the form of new goods as shown in the existing differences between the law and Regulation of the Minister of Trade with the Regulation of the Minister of Finance as well as the efforts to harmonize and synchronize the differences found in the regulations of imported new goods. This was a normative legal research, with statute approach. The results and discussion of this research showed that the factors causing the different arrangements of imported new goods are related to the background of the establishment of the legislations, namely the Trade Law, Regulation of the Minister of Trade No. 48/M-DAG/PER/7/2015, Regulation of the Minister of Trade No. 51/M-DAG/PER/7/2015, and Regulation of the Minister of Finance No. 6/PMK.010/PER/2017 and the fact that the theory of legal system is not implemented because such legal system contains the stages of the formulation of laws and regulations which include harmonization and synchronization among Pancasila, the 1945 Constitution, and legislation. Law is declared to be valid if it is sourced and based on norms established by higher norms, in this case the principle of lex superiori derogate legi inferiori. An effort to harmonize and synchronize the differences in the arrangement of imported new goods is to pay attention to the procedures for the establishment of legislation especially regarding the harmonization and synchronization stage that must be undertaken by the Directorate General of Legislation (DJPP)
\end{abstract}

Keywords: Imported goods; harmonization; synchronization

\section{Abstrak}

Penelitian ini bertujuan untuk mengetahui dan mengkaji faktor penyebab terjadinya perbedaan pengaturan barang impor dalam keadaan baru sebagaimana adanya undang-undang dan Peraturan Menteri Perdagangan berbeda pengaturannya dengan Peraturan Menteri Keuangan serta upaya dalam mengharmoniskan dan menyinkronkan perbedaan pengaturan barang impor dalam keadaan baru. Jenis penelitian yang digunakan adalah penelitian hukum normatif, dengan pendekatan perundang-undangan. Hasil penelitian dan pembahasan menunjukan bahwa faktor penyebab terjadinya perbedaan pengaturan terhadap barang impor dalam keadaan baru adalah dari latar belakang dibentuk peraturan perundang-undangan yaitu Undang-Undang Perdagangan, Permendag No. 48/MDAG/PER/7/2015, Permendag No. 51/M-DAG/PER/7/2015, dan Peraturan Menteri Keuangan Nomor 6/PMK.010/PER/2017 dan teori sistem hukum tidak diterapkan karena dalam sebuah sistem hukum adanya tahapan pembentukan peraturan perundang-undangan yang salah satunya berupa harmonisasi dan sinkronisasi antara Pancasila, UUD 1945, dan peraturan perundang-undangan. Hukum itu sah apabila bersumber dan berdasar pada norma yang dibentuk oleh norma yang lebih tinggi, dalam hal ini asas lex superiori derogate legi inferiori. Upaya untuk mengharmoniskan dan menyinkronkan perbedaan pengaturan barang impor dalam keadaan baru adalah memperhatikan prosedur pembentukan peraturan perundang-undangan terhadap tahapan harmonisasi dan sinkronisasi yang harus dilakukan oleh Direktorat Jenderal Peraturan Perundangan (DJPP).

Kata-kata Kunci: Barang impor; harmonisasi; sinkronisasi 


\section{Pendahuluan}

Impor adalah kegiatan memasukkan barang ke dalam Daerah Pabean, sedangkan Importir adalah orang perseorangan atau lembaga atau badan usaha, baik yang berbentuk badan hukum maupun bukan badan hukum, yang melakukan impor. Kegiatan perdagangan internasional khususnya di bidang impor, negaranegara bergerak dalam kegiatan tersebut mempunyai tujuan-tujuan yang hendak dicapai yakni pengadaan bahan-bahan pokok kebutuhan dalam negeri yang belum dapat dihasilkan dalam negeri, pengadaan bahan-bahan modal yang belum cukup dihasilkan, dan pertumbuhan industri guna memenuhi kebutuhan dalam negeri dan untuk diekspor. ${ }^{1}$ Tidak semua barang impor dapat masuk ke Indonesia karena adanya klasifikasi barang-barang impor dalam pengawasan bea cukai yaitu barang dilarang, dibatasi, atau ditentukan lain oleh Undang-Undang. UUD NRI Tahun 1945, khususnya Pasal 33 ayat (1) dan (4) berisi perihal perekonomian disusun sebagai usaha bersama berdasar atas asas kekeluargaan dan diselenggarakan berdasar atas demokrasi ekonomi. Demokrasi ekonomi mengutamakan kepentingan rakyat yang tertuang dalam Ketetapan Majelis Permusyawaratan Rakyat Republik Indonesia Nomor XVI/MPR/1998 tentang Politik Ekonomi dalam Rangka Demokrasi Ekonomi. Sejalan dengan perkembangan kebutuhan dan tantangan, pembangunan nasional politik ekonomi dalam ketetapan ini mencakup kebijaksanaan strategi dan pelaksanaan pembangunan ekonomi nasional sebagai perwujudan dari prinsip-prinsip dasar demokrasi ekonomi.

Peraturan perundang-undangan di bidang perdagangan mengharuskan adanya harmonisasi dalam kerangka kesatuan ekonomi nasional guna menyikapi perkembangan situasi perdagangan era globalisasi pada masa kini dan masa depan. Pengaturan barang impor dalam keadaan baru diatur dalam peraturan perundang-undangan sebagai berikut. Undang-Undang Nomor 7 Tahun 2014 tentang Perdagangan (selanjutnya ditulis UU Perdagangan), secara tegas dalam Pasal 47 ayat (1) berisikan bahwa "setiap importir wajib mengimpor barang dalam keadaan baru", sehingga importir dilarang mengimpor barang dalam keadaan tidak baru kecuali dalam hal tertentu.

\footnotetext{
${ }^{1}$ Maringan Lumban Raja, Faktor-faktor Yang Mempengarubi Eksportir dan Importir dalam Perdagangan Luar Negeri (International Sale of Goods), Universitas Diponogoro, Semarang, 1998, hlm. 53.
} 
Terdapat peraturan menteri perdagangan dan peraturan menteri keuangan yang mengatur tentang kualifikasi barang impor yang secara eksplisit berbeda. Peraturan Menteri Perdagangan Nomor 48/M-DAG/PER/7/2015 tentang Ketentuan Umum Bidang Impor (selanjutnya ditulis PERMENDAG No. 48/MDAG/PER/7/2015), Pasal 2 ayat (1) yang menyatakan bahwa "Barang yang diimpor harus dalam keadaan baru" dan Peraturan Menteri Perdagangan Nomor 51/M-DAG/PER/7/2015 tentang Larangan Impor Pakaian Bekas (selanjutnya ditulis PERMENDAG No. 51/M-DAG/PER/7/2015), di dalam Pasal 2 diatur "Pakaian Bekas dilarang untuk diimpor ke dalam wilayah Negara Kesatuan Republik Indonesia". Sedangkan Peraturan Menteri Keuangan Nomor 6/PMK.010/2017 tentang Penetapan Klasifikasi Barang dan Pembebanan Tarif Bea Masuk Atas Barang Impor (selanjutnya ditulis PERMENKEU No. 6/PMK.010/2017), di dalam Lampiran III Nomor 5557 Pos Tarif/HS Code 6309.00.00.6310 mengatur bahwa pakaian bekas dan barang bekas lainnya dikenakan bea masuk 35\% sehingga, peraturan menteri perdagangan dan keuangan tidak adanya harmonisasi dan sinkronisasi antara satu dengan yang lainnya yang dapat berdampak tidak adanya suatu kepastian hukum yang merupakan salah satu tujuan hukum.

Kurangnya harmonisasi antar peraturan menteri keuangan dan peraturan menteri perdagangan mengenai kualifikasi barang impor berupa produk yang baru. Kutipan surat kabar online liputan6.com pada 27 Juli 2015 bahwa dua aturan berbeda soal impor pakaian bekas dari Kementerian Keuangan dan Kementerian Perdagangan. Hal ini memicu kekhawatiran bea cukai yang bertindak sebagai pengawas di lapangan. Menanggapi aturan tersebut, Menteri Keuangan Bambang Brodjonegoro bahwa kenaikan tarif bea masuk menjadi antisipasi atau cadangan bagi aturan Menteri Perdagangan tentang larangan impor pakaian bekas, dengan mengatakan bahwa. ${ }^{2}$

"Bea Cukai harus ikut aturan Kementerian Perdagangan. Ketentuan boleh impor atau tidak, suatu saat bisa dicabut. Jika larangan impor baju bekas

2"Larangan Impor Baju Bekas Dihapus, Tarif Bea Masuk Menjadi Pengganti" http:/ / bisnis.liputan6.com/read/2280474/larangan-impor-baju-bekas-dihapus-tarif-bea-masuk-jadi-pengganti, di akses pada tanggal 16 November 2016 
dicabut, bea masuk berlaku. Tapi kalau ketentuannya dilarang impor, berarti yang berlaku peraturan menteri perdagangan."

Kementerian Keuangan menjadikan pakaian bekas sebagai objek pengenaan bea $^{3}$ masuk kendati Kementerian Perdagangan melarang importasi komoditas tersebut. Barang haram tersebut dikenakan tarif bea masuk sebesar $35 \%$ dari harga dasar. Hal itu tertuang dalam Peraturan Menteri Keuangan Nomor 132/0.10/2015 tentang Penetapan Sistem Klasifikasi Barang dan Pembebanan Tarif Bea Masuk Atas Barang Impor, yang terbit pada 9 Juli 2015 bahwa aturannya bahwa pakaian bekas impor dikenakan tarif hingga 35\%. Direktur Jenderal Bea dan Cukai, Heru Pambudi, mengamini perkataan, Bambang Brodjonegoro (Menteri Keuangan) bahwa "penerapan tarif baru bea masuk tersebut mampu melindungi industri garmen domestik yang saat ini digempur oleh produk luar negeri. Jangan sampai pakaian bekas menggerus pangsa pasar dari industri legal. ${ }^{4}$

Uraian yang telah dijelaskan di atas dan peraturan perundang-undangan yang berlaku saat ini menyebabkan tidak adanya suatu kepastian hukum untuk para pelaku usaha dan masyarakat mengenai barang impor dalam keadaan baru, jawaban dari Menteri Perdagangan dan Keuangan juga tidak memberikan kepastian dan kejelasan, karena tujuan hukum harus memberikan perlindungan dan kepastian hukum kepada seluruh masyarakat dan pelaku usaha. Ketidakharmonisasian antara peraturan menteri perdagangan dan peraturan menteri keuangan membuat suatu tanda tanya besar sehingga ini dapat menjadi celah hukum bagi pelanggarannya. Berdasarkan penjelasan tersebut dapat

\footnotetext{
${ }^{3}$ Bea adalah pajak yang dipungut atas keluar masuknya daerah pabean. Bea berbeda dengan pajak karena pajak menurut pendapat S.I Djajadiningrat adalah sebagai suatu kewajiban menyerahkan sebagian daripada kekayaan kepada negara disebabkan suatu keadaan, kejadian dan perbuatan yang memberikan kedudukan tertentu, tetapi bukan sebagai hukuman, menurut peraturan-peraturan yang ditetapkan pemerintah serta dapat dipaksakan, tetapi tidak ada jasa balik dari negara secara langsung, untuk memelihara kesejahteraan umum. Tetapi meskipun berbeda keduanya mempunyai kesamaan, pajak-pajak bea dan cukai merupakan peralihan kekayaan dari sektor swasta ke sektor pemerintah, yang diharuskan oleh undang-undang dan dapat dipaksa, dengan tidak mendapat jasa timbal (tegenprestatie) yang langsung dapat ditunjuk, untuk membiayai pengeluaran-pengeluaran negara. Selain itu persamaannya bahwa berbagai jenis pajak, bea masuk, bea keluar dan cukai merupakan sumber-sumber penerimaan negara. Lihat di Meiti Asmorowati, "Pembebasan Bea Masuk Atas Impor Buku Ilmu Pengetahuan Berdasarkan Pasal 25 UU No. 17 Tahun 2006 jo SK Menkeu No. 103/Kmk.04/2007”, Jurnal Wawasan Hukum, Vol. 26 No. 01, Februari 2012, hlm. 521.

"Impor Baju Bekas Dilarang namun Masih Kena Bea Masuk 35\%" http://www.cnnindonesia.com/ekonomi/20150727140602-78-68349/impor-baju-bekas-dilarang-namun-masihkena-bea-masuk-35/, di akses pada tanggal 16 November 2016
} 
dilakukannya penelitian ini mengenai "Harmonisasi dan Sinkronisasi Hukum Terhadap Perbedaan Pengaturan Barang Impor Dalam Keadaan Baru".

\section{Rumusan Masalah}

Berdasarkan latar belakang yang telah dipaparkan, maka dirumuskan masalah Pertama, apa faktor penyebab terjadinya perbedaan pengaturan barang impor dalam keadaan baru? Kedua, bagaimanakah upaya untuk mengharmoniskan dan menyinkronkan perbedaan pengaturan barang impor dalam keadaan baru?

\section{Tujuan Penelitian}

Sesuai dengan rumusan masalah, maka tujuan penelitian ini: pertama, untuk mengkaji faktor penyebab terjadinya perbedaan pengaturan barang impor dalam keadaan baru. Kedua, untuk mengkaji upaya dalam mengharmoniskan dan menyinkronkan perbedaan pengaturan barang impor dalam keadaan baru.

\section{Metode Penelitian}

Jenis penelitian yang digunakan adalah hukum normatif. Penelitian hukum normatif menggunakan data sekunder. Pendekatan penelitian yang digunakan dalam penulisan hukum ini adalah pendekatan perundang-undangan. Peter Mahmud Marzuki memberikan pendapat, pendekatan perundang-undangan merupakan pendekatan yang dilakukan dengan menelaah semua undang-undang dan regulasi yang bersangkut paut dengan isu hukum yang sedang ditangani. ${ }^{5}$

Sumber data yang digunakan adalah bahan hukum primer, bahan hukum sekunder, dan bahan hukum tersier. Bahan hukum primer dalam penelitian ini adalah Undang-Undang Dasar Republik Indonesia 1945 Pasal 33 ayat (1) dan (4), Undang-Undang Nomor 7 Tahun 2014 tentang Perdagangan, Undang-Undang Nomor 17 Tahun 2006 tentang Perubahan Atas Undang-Undang Nomor 10 Tahun 1995 tentang Kepabeanan, Undang-Undang Nomor 12 Tahun 2011 tentang Pembentukan Peraturan Perudang-undangan, Peraturan Presiden Nomor 44 Tahun 2015 tentang Kementerian Hukum Dan Hak Asasi Manusia, Peraturan Menteri Perdagangan Nomor 48/M-DAG/PER/7/ 2015 tentang Ketentuan Umum

${ }_{5}^{5}$ Peter Mahmud Marzuki, Penelitian Hukum. Prenada Media Group, Jakarta, 2016, hlm. 133. 
Bidang Impor, Peraturan Menteri Perdagangan Nomor 51/M-DAG/PER/7/2015 tentang Larangan Impor Pakaian Bekas, Peraturan Menteri Keuangan Nomor 6/PMK.010/2017 tentang Penetapan Klasifikasi Barang dan Pembebanan Tarif Bea Masuk Atas Barang Impor, dan Peraturan Menteri Hukum Dan Hak Asasi Manusia Nomor 30 Tahun 2015 tentang Tata Cara Pembentukan Peraturan Menteri Di Lingkungan Kementerian Hukum Dan Hak Asasi Manusia. Bahan hukum sekunder merupakan pendapat ahli dan pendapat hukum yang diperoleh dari buku, jurnal, surat kabar, hasil penelitian, internet, dan narasumber. Bahan hukum tersier berupa Kamus Besar Bahasa Indonesia dan kamus hukum.

Metode pengumpulan data yang digunakan dalam penelitian ini dilakukan melalui: pertama, studi kepustakaan, studi dokumen, yaitu untuk menemukan bahan hukum primer berupa peraturan perundang-undangan dan bahan hukum sekunder berupa pendapat bukan hukum yang diperoleh dari buku, jurnal, surat kabar, hasil penelitian, internet, dan narasumber serta bahan hukum tersier berupa Kamus Besar Bahasa Indonesia dan kamus hukum. Kedua, wawancara dilakukan terhadap narasumber yaitu Kepala KPPBC Tipe Madya Pabean B Yogyakarta, secara langsung dengan mengajukan pertanyaan yang sudah disiapkan guna mendapatkan informasi. Proses berpikir yang digunakan secara induktif. Bertolak dari fakta-fakta khusus yaitu bahwa karena secara garis besar barang impor dapat masuk ke Indonesia akan tetapi secara khusus ada pengaturannya yaitu barang impor harus dalam keadaan baru sebagaimana yang diatur dalam UndangUndang dan Peraturan Menteri Perdagangan dan berakhir pada kesimpulan atau pengetahuan baru yang bersifat umum merupakan hasil penelitian mengenai adanya harmonisasi dan sinkronisasi hukum terhadap perbedaan pengaturan barang impor dalam keadaan baru.

\section{Hasil Penelitian dan Pembahasan}

\section{Faktor Penyebab Terjadinya Perbedaan Pengaturan Barang Impor dalam Keadaan Baru}

Pengaturan mengenai barang impor dalam keadaan baru dinyatakan berbeda sebagaimana diatur dalam UU Perdagangan, PERMENDAG No. 48/MDAG/PER/7/2015, dan PERMENDAG No. 51/M-DAG/PER/7/2015 berbeda 
dengan PERMENKEU No. 6/PMK.010/PER/2017. Faktor-faktor penyebab terjadi perbedaan pengaturan barang impor dalam keadaan baru diuraikan dan dijelaskan dalam alinea selanjutnya.

Penjelasan umum UU Perdagangan, perdagangan nasional Indonesia sebagai penggerak utama perekonomian tidak hanya terbatas pada aktivitas perekonomian yang berkaitan dengan transaksi barang dan/atau jasa yang dilakukan oleh pelaku usaha, baik di dalam negeri maupun melampaui batas wilayah negara, tetapi aktivitas perekonomian yang harus dilaksanakan dengan mengutamakan kepentingan nasional Indonesia yang diselaraskan dengan konsepsi pengaturan di bidang perdagangan sesuai dengan cita-cita pembentukan negara Indonesia, yaitu masyarakat adil dan makmur sebagaimana diamanatkan dalam Pembukaan UUD NRI Tahun 1945. Sebagaimana yang dimaksud dalam konsiderans PERMENDAG No. 48/M-DAG/PER/7/2015 dibentuk dalam rangka memenuhi kebutuhan atas barang yang belum dapat diperoleh dari sumber di dalam negeri baik untuk keperluan produksi industri nasional maupun konsumsi masyarakat, perlu upaya untuk meningkatkan penataan tertib impor dengan menyempurnakan kembali ketentuan-ketentuan di bidang impor agar menjadi lebih transparan, efektif dan efisien serta berkesinambungan. Dibentuknya PERMENDAG No. 51/MDAG/PER/7/2015, berdasarkan konsideran bahwa pakaian bekas asal impor berpotensi membahayakan kesehatan manusia sehingga tidak aman untuk dimanfaatkan dan digunakan oleh masyarakat dan untuk melindungi kepentingan konsumen, maka perlu melarang impor pakaian bekas.

Pengaturan dalam UU Perdagangan, PERMENDAG No. 48/MDAG/PER/7/2015 dan PERMENDAG No. 51/M-DAG/PER/7/2015, mengatur bahwa ketentuan barang impor dalam keadaan baru dapat dikategorikan dengan mengkaji dan menganalisis tentang pengertian keadaan baru tersebut. Pengertian baru berdasarkan Kamus Besar Bahasa Indonesia adalah belum pernah ada (dilihat) sebelumnya; belum lama selesai; terakhir. ${ }^{6}$ Dengan demikian, klasifikasi barang impor dalam keadaan baru berupa setiap benda yang sama sekali belum

${ }^{6}$ Departemen Pendidikan Nasional, Kamus Besar Bahasa Indonesia, Edisi Keempat, Gramedia Pustaka Utama, Jakarta, 2012, hlm. 109. 
pernah digunakan, dipakai, dibuka bungkusannya, dan pertama kali produk tersebut yang akan diperjual belikan atau dikeluarkan tanpa campur tangan yang lain dalam arti kondisi masih bagus dan belum lama selesai, selanjutnya akan dimpor atau masuk ke wilayah pabean Indonesia. Barang impor dalam keadaan baru diproduksi sesuai dengan standar dan mekanisme yang benar serta layak digunakan atau dipakai.

Pengaturan barang impor dalam keadaan baru bertujuan melindungi masyarakat dari aspek kesehatan yaitu menghindar/mencegah berbagai penyakit yang berbahaya karena ada kandungan jamur dan bakteri terutama pada pakaian bekas dan dari aspek industri melindungi usaha konveksi/industri garmen kecil dalam negeri. Selain itu, tujuannya barang impor dalam keadaan baru agar Indonesia bukan merupakan tempat pembuangan akhir terhadap barang-barang bekas dari negara lain, terutama barang impor dalam keadaan tidak baru tersebut tidak dapat didaur ulang kembali. Dampak dari pengaturan barang impor dalam keadaan baru berupa konveksi/industri garmen kecil dapat bersaing, penyakit berbahaya dapat terhindar, dan masyarakat akan mendapatkan produk barang yang terbaik. Perlindungan hukum industri garmen dalam negeri, terhadap impor pakaian bekas yaitu, pemerintah harus lebih memberi kesempatan dan memberi bantuan kepada industri garmen lokal, dan juga beberapa keringanan misalnya meminimalkan pajak yang besar atau pajak ganda, yang dikenakan pada industri garmen dalam negeri atau industri yang pangsa pasar ekspor, tingginya suku bunga, berdampak pada lemahnya daya saing industri tekstil di Indonesia, khususnya di Kota Palu bukan semata-mata disebabkan oleh banyak masuk produk tekstil pakaian bekas yang membanjiri pasar domestik di Kota Palu, hal ini disebabkan secara fundamental sangat dipengaruhi oleh kelembagaan yang ada dalam industri di indonesia. Kendala hukum dalam proteksi impor pakaian bekas yang merugikan industri garmen dalam negeri yaitu, salah satunya dipengaruhi lemahnya aparatur pemerintah Pusat dan pemerintah daerah dalam memproteksi maraknya importir pakaian bekas, hal ini merusak harga impor garmen lokal, di samping itu kendalanya adanya perubahan harga garmen dunia, tarif impor garmen, produksi garmen Indonesia, jumlah penduduk Indonesia, impor garmen 
Indonesia, dan lain sebagainya.7 Barang impor dalam keadaan baru akan lebih memberi manfaat dan sebuah kelayakan untuk digunakan oleh masyarakat dibandingkan barang impor dalam keadaan tidak baru.

PERMENKEU No. 6/PMK.010/PER/2017 tentang Penetapan Klasifikasi Barang Dan Pembebanan Tarif Bea Masuk Atas Barang Impor, yang mengatur barang impor, sebagaimana tercantum dalam Pasal 1 ayat (2) bahwa, Lampiran I, Lampiran II, dan Lampiran III sebagaimana dimaksud pada ayat (1), merupakan bagian tidak terpisahkan dari Peraturan Menteri ini. Maka dari itu dalam lampiran III tentang penetapan sistem klasifikasi barang dan pembebanan tarif bea masuk atas impor barang, dengan Nomor 5557 Pos Tarif/HS Code 6309.00.00.6310 bahwa pakaian bekas dan barang bekas lainnya dikenakan bea masuk 35\%. Dibentuknya PERMENKEU No. 6/PMK.010/PER/2017 didasarkan pada konsideran, dikarenakan sebagai berikut:

1. Sehubungan dengan adanya amandemen terhadap Harmonized System (HS) 2012 menjadi Harmonized System (HS) 2017 dan revisi ASEAN Harmonised Tariff Nomenclature (AHTN) 2012 menjadi ASEAN Harmonised Tariff Nomenclature (AHTN) 2017, perlu melakukan perubahan terhadap sistem klasifikasi barang sebagaimana diatur dalam Peraturan Menteri Keuangan Nomor 213/PMK.011/2011 tentang Penetapan Sistem Klasifikasi Barang dan Pembebanan Tarif Bea Masuk atas Barang Impor sebagaimana telah beberapa kali diubah terakhir dengan Peraturan Menteri Keuangan Nomor 134/PMK.O10/2016. Harmonized System atau biasa disebut HS adalah suatu daftar penggolongan barang yang dibuat secara sistematis dengan tujuan mempermudah penarifan, transaksi perdagangan, pengangkutan dan statistik yang telah diperbaiki dari sistem klasifikasi sebelumnya. Saat ini pengklasifikasian barang di Indonesia didasarkan kepada Harmonized System dan dituangkan ke dalam suatu daftar tarif yang disebut Buku Tarif Bea Masuk Indonesia (BTBMI). Tujuan daripada pembuatan HS ini di antaranya adalah: ${ }^{8}$

a. Memberikan keseragaman dalam penggolongan daftar barang yang sistematis.

b. Memudahkan pengumpulan data dan analisis statistik perdagangan dunia.

c. Memberikan sistem internasional yang resmi untuk pemberian kode, penjelasan dan penggolongan barang untuk tujuan perdagangan

2. Berdasarkan pertimbangan dan untuk melaksanakan ketentuan Pasal 12 dan 14 Undang-Undang Nomor 10 Tahun 1995 tentang Kepabeanan sebagaimana telah

\footnotetext{
${ }^{7}$ Nur Rahmi Djalali, "Perlindungan Hukum Industri Garmen Dalam Negeri, Terhadap Impor Pakaian Bekas”, Jurnal Ilmu Hukum Legal Opinion Edisi 2, Volume 3, 2015, hlm. 7-8.

8 "Definisi dan Manfaat" http://djpen.kemendag.go.id/app_frontend/contents/147-definisi-manfaat, diakses tanggal 26 September 2017
} 
diubah dengan Undang-Undang Nomor 17 Tahun 2006 tentang Perubahan atas Undang-Undang Nomor 10 Tahun 1995 tentang Kepabeanan, perlu menetapkan peraturan menteri keuangan tentang penetapan sistem klasifikasi barang dan pembebanan tarif bea masuk atas barang impor.

PERMENKEU No. 6/PMK.010/PER/2017 dibentuk karena Indonesia merupakan anggota dari Perserikatan Bangsa-bangsa Asia Tenggara (ASEAN) sehingga Indonesia mengikuti aturan yang telah disepakati bersama sesuai Pasal 13 UU Kepabeanan, barang impor yang dikenakan tarif bea masuk berdasarkan perjanjian atau kesepakatan internasional. Pembentukannya peraturan menteri keuangan bertujuan untuk menyamankan dan menyelaraskan tarif bea masuk barang impor terhadap sesama anggota Perserikatan Bangsa-Bangsa Asia Tenggara (ASEAN). Agar mempermudah dalam perhitungan tarif bea masuk dan memperlancar kegiatan impor peraturan ini diberlakukan dalam kawasan Asia Tenggara.

Sehubung dengan adanya pembentukan Peraturan Menteri Keuangan ini, dapat dikaji bahwa pembentuk peraturan perundang-undangan dalam hal ini Menteri Keuangan tidak mempertimbangkan dan tidak melakukan harmonisasi dan sinkronisasi terhadap peraturan perundang-undangan yang berkaitan dengan barang impor terutama barang impor dalam keadaan baru. Diketahui bahwa dalam UU Perdagangan, PERMENDAG No. 48/M-DAG/PER/7/2015 dan PERMENDAG No. 51/M-DAG/PER/7/2015 mengatur barang impor dalam keadaan baru akan tetapi PERMENKEU No. 6/PMK.010/PER/2017 memperbolehkan pakaian bekas dan barang bekas dapat dimpor dengan dikenai tarif bea masuk sebesar 35\%. Perbedaan pengaturan tersebut dapat dikaji bahwa berdasarkan latar belakang dan tujuan dibentuknya dari keempat peraturan tersebut.

Perbedaan pengaturan tentang barang impor dalam keadaan baru dapat dikaji berdasarkan teori sistem hukum bahwa tahapan-tahapan pembentukan peraturan perundang-undangan tidak dilaksanakan. Tahapan pembentukan peraturan perundang-undangan dalam sebuah sistem hukum mengharuskan adanya harmonisasi dan sinkronisasi antara Pancasila, UUD NRI Tahun 1945, dan peraturan perundang-undangan karena sistem hukum merupakan satu kesatuan 
yang tidak dapat dipisahkan dan saling berhubungan. Sebuah sistem hukum dapat berjalan jika keseluruhan peraturan perundang-undangan sejalan dan tidak berbenturan satu sama yang lain.

Pertentangan antar peraturan perundang-undangan menjadi salah satu masalah hukum di Indonesia yang tidak kunjung selesai. Banyak produk hukum yang dihasilkan Dewan Perwakilan Rakyat maupun pemerintah tidak sinkron dengan peraturan lain, baik yang setara maupun lebih tinggi kedudukannya. Kualitas yang tidak maksimal terhadap harmonisasi dan sinkronisasi rancangan peraturan perundang-undangan jadi perhatian utama banyak pemerhati hukum. Kemenkumham sebagai penanggungjawab dianggap tidak melakukan harmonisasi dan sinkronisasi dengan baik rancangan peraturan dengan peraturan yang sudah ada. Tidak sedikit aturan baru yang bertentangan dengan aturan yang berlaku lebih dulu. M. Aliamsyah, staf Direktorat Publikasi Kerjasama dan Pengundangan Direktorat Jenderal Peraturan Perundang-Undangan Kementerian Hukum dan Hak Asasi Manusia, berpendapat bahwa. ${ }^{9}$

"proses harmonisasi dan sinkronisasi sering terkendala akibat tidak lengkapnya data peraturan perundang-undangan yang dimiliki dan masih terdapat kesulitan pengelolaan sistem informasi peraturan perundangundangan yang terpadu dan akurat. Kesulitan dalam administrasi peraturan di kementerian atau lembaga negara tidak begitu baik. Seringkali prosesnya lama untuk sampai di Kemenkumham. Bahkan, ada berkas peraturan yang sudah diunggah ke jaringan database Kemenkumham diminta kembali oleh kementerian yang bersangkutan dengan alasan perlu perbaikan redaksional yang sebenarnya sudah ditandatangani menteri."

Dapat dikaji bahwa perbedaan pengaturan terhadap barang impor dalam keadaan baru terjadi karena hukum itu sah apabila bersumber dan berdasar pada norma yang dibentuk oleh norma yang lebih tinggi, dalam hal ini asas lex superiori derogate legi inferiori. Kualitas proses harmonisasi dan sinkronisasi yang tidak maksimal dalam pelaksanaan karena ketidaklengkapnya peraturan perundangundangan dan administrasi peraturan di kementerian serta proses yang lama menjadi kendala sehingga menyebabkan peraturan perundang-undangan menjadi

\footnotetext{
"Minimnya Database Peraturan, Mempersulit Harmonisasi Hukum" http://www.hukumonline.com/berita/baca/lt4d0989a80b9af/minimnya-idatabasei-peraturan-persulitharmonisasi-hukum, diakses pada tanggal 11 September 2017.
} 
berbenturan karena tidak adanya sistem yang dapat melacak jika suatu aturan tersebut tidak sinkron atau harmonis. Kepastian hukum dibutuhkan dalam kegiatan bisnis, oleh karena itu perbedaan pengaturan barang impor dalam keadaan baru berdampak merugikan masyarakat.

Konsep kepastian hukum berupa kejelasan hierarki dan konsistensi peraturan perundang-undangan. Kejelasan hierarki merupakan lembaga yang berwenang dalam pembentukan peraturan perundang-undangan dan tata uratan peraturan perundang-undangan yang diatur dalam Pasal 7 UU Nomor 12 Tahun 2011 tentang Pembentuk Peraturan Perundang-Undangan, sedangkan konsistensi peraturan perundang-undangan merupakan ketentuan sejumlah peraturan perundangundangan yang tidak bertentangan antara satu dengan lainnya. Konsep kepastian hukum dalam PERMENKEU No. 6/PMK.010/PER/2017 dengan peraturan di atas (vertikal) yaitu UU tentang Perdagangan dan Peraturan yang sejajar (horizontal) PERMENDAG No. 48/M-DAG/PER/7/2015 dan PERMENDAG No. 51/MDAG/PER/7/2015, dapat dikaji bahwa kejelasan hierarki terhadap lembaga pembentuk yang berwenang telah dipenuhi sebagaimana peraturan menteri perdagangan dibentuk oleh Menteri Perdagangan sedangkan peraturan menteri keuangan dibentuk oleh Menteri Keuangan, akan tetapi tidak adanya konsistensi proses pembentukan Peraturan Menteri tersebut karena yang terjadi adanya ketidakharmonisasian dan sinkronisasian UU perdagangan, Peraturan Menteri Perdagangan, dan Peraturan Menteri Keuangan.

Hasil wawancara dari Kepala KPPBC Tipe Madya Pabean B Yogyakarta dalam hal ini diwakilkan oleh bagian Layanan Penyuluhan dan Informasi Bea Cukai, Bapak Hermoko dan Ibu Indah ${ }^{10}$, sebagaimana hasil wawancara tersebut merupakan data pendukung dalam penelitian ini. Hasil wawancara memberikan pernyataan bahwa Bapak Hermoko dan Ibu Indah tidak sependapat mengenai adanya perbedaan pengaturan barang impor dalam keadaan baru yang telah dijabarkan dan dijelaskan dalam penelitian ini. Bapak Hermoko dan Ibu Indah memberikan pendapat dengan merujuk adanya INSW (Indonesian National Single Window), PERMENKEU No. 6/PMK.010/PER/2017 khususnya lampiran yang

${ }^{10}$ Hasil wawancara Kepala KPPBC Tipe Madya Pabean B Yogyakarta diwakilkan oleh Bagian Layanan Penyuluhan dan Informasi Bea Cukai, Hermoko dan Indag pada tanggal 30 November 2017. 
mengenai tarif bea masuk pakaian bekas dan barang bekas dikenai $35 \%$ tidak menyatakan boleh atau tidak, berdarkan Pasal 2 ayat (2) PERMENDAG No. 48/MDAG/PER/7/2015 mengenai "dalam hal tertentu, Menteri dapat menetapkan barang impor dalam keadaan tidak baru berdasarkan peraturan perundangundangan, kewenangan Menteri, dan/atau ususan atau pertimbangan teknis dari instansi pemerintah lainnya", Pasal 53 ayat (1) Undang-Undang Nomor 17 Tahun 2006 tentang Perubahan Atas Undang-Undang Nomor 10 Tahun 1995 tentang Kepabeanan (selanjutnya ditulis UU Kepabeanan) bahwa, "untuk kepentingan pengawasan terhadap pelaksanaan ketentuan larangan dan pembatasan, instansi teknis yang menetapkan peraturan larangan dan/atau pembatasan atas impor atau ekspor wajib memberitahukan kepada Menteri", dan Pasal 5 ayat (2) Peraturan Menteri Keuangan Nomor 224/PMK.04/2015 tentang Pengawasan Terhadap Impor atau Ekspor Barang Larangan dan/atau Pembatasan bahwa barang impor atau ekspor dapat diberikan persetujuan pengeluaran barang dari kawasan pabean atau tempat lain yang diperlakuan sama dengan tempat penimbunan sementara untuk diimpor atau diekspor, setelah memenuhi ketentuan larangan dan/atau pembatasan.

Hasil wawancara tersebut, Peneliti berpendapat lain. Pertama, mengenai Indonesian National Single Window (selanjunya ditulis INSW) merupakan sistem nasional Indonesia yang memungkinkan dilakukannya suatu penyampaian data dan informasi secara tunggal (single submission of data and information), pemrosesan data dan informasi secara tunggal dan sinkron (single and synchronous processing of data and information), dan pembuatan keputusan secara tunggal untuk pemberian izin kepabeanan dan pengeluaran barang (single decision making for customs clearance and release of cargoes). INSW berfungsi sebagai berikut: ${ }^{11}$

1. Sistem INSW menampung semua database perijinan berdasarkan peraturan dari instansi teknis (GA-Government Agency) meliputi larangan dan pembatasan di bidang impor.

2. Instansi teknis terkait meng-upload perijinan yang diterbitkannya ke Portal INSW.

11 “Tentang INSW” http:/ / bctemas.beacukai.go.id/faq/tentang-insw/, diakses pada tanggal 30 November 2017. 
3. Portal INSW akan melakukan pengecekan kesesuaian data PIB (Pemberitahuan Impor Barang) yang dikirim oleh Importir/PPJK secara elektronik dengan DATABASE LARTAS IMPOR berdasarkan parameter Nomor HS.

4. Dalam hal Nomor HS membutuhkan perijinan, maka Sistem INSW akan mengecek kesesuaian data PIB dengan perijinan terkait berdasarkan parameter Nomor Aju PIB, NPWP, nomor dan tanggal perijinan, kode ijin dan masa berlaku.

5. Dalam hal pengecekan kesesuaian data PIB dengan perijinan terkait memerlukan penelitian lebih lanjut karena Nomor HS pada PIB tidak mutlak wajib ijin, maka portal INSW akan memberikan respon Analysing Point, selanjutnya petugas Analysing Point pada kantor pengawasan dan pelayanan bea dan cukai akan melakukan pengecekan kesesuaian data PIB dengan perijinan terkait.

6. Dalam hal pengecekan kesesuaian data PIB dengan perijinan terkait tidak memerlukan penelitian lebih lanjut karena nomor HS pada PIB mutlak wajib ijin, maka portal INSW akan langsung melakukan pengecekan oleh sistem.

7. Jika proses pengecekan data PIB dengan perijinan terkait sesuai, maka portal INSW akan meneruskan data PIB ke sistem komputer kantor bea dan cukai terkait untuk diproses lebih lanjut (proses penjaluran).

8. Jika tidak sesuai, maka Portal INSW akan memberikan respon penolakan secara elektronik melalui Modul EDI Importir PPJK.

INSW merupakan pengecekan ijin dan pengecekan kesesuaian mengenai barang dilarang dan/atau pembatasan barang impor. Dalam PERMENKEU No. 6/PMK.010/PER/2017 khususnya lampiran yang mengenai tarif bea masuk pakaian bekas dan barang bekas dikenai 35\% mengenai masalah tidak menyatakan boleh atau tidak, jika tidak diperbolehkan, tidak akan ada lampiran tersebut, maka dari itu lampiran tersebut berfungsi sebagai pelengkap dan merupakan satu kesatuan yang tidak dapat dipisahkan sesuai Pasal 1 ayat (3) PERMENKEU No. 6/PMK.010/PER/2017.

Pasal 2 ayat (2) PERMENDAG No. 48/M-DAG/PER/7/2015 mengenai "dalam hal tertentu", sebagaimana yang telah dijelaskan dalam penjelasan UU Perdagangan bahwa dalam hal barang yang dibutuhkan oleh pelaku usaha berupa barang modal bukan baru yang belum dapat dipenuhi dari sumber dalam negeri sehingga perlu diimpor dalam rangka proses produksi industri untuk tujuan pengembangan ekspor, peningkatan daya saing, efisiensi usaha, investasi dan relokasi industri, pembangunan infrastruktur, dan/atau diekspor kembali dan selain itu, dalam hal terjadi bencana alam dibutuhkan barang atau peralatan dalam kondisi tidak baru dalam rangka pemulihan dan pembangunan kembali sebagai 
akibat bencana alam serta barang bukan baru untuk keperluan lainnya sesuai dengan ketentuan peraturan perundang-undangan.

Pasal 53 ayat (1) UU Kepabeanan dan Pasal 5 ayat (2) Peraturan Menteri Keuangan Nomor 224/PMK.04/2015 dapat ditafsirkan atau diinterpretasikan bahwa adanya pengecualian dengan permintaan persetujuan dari Menteri terhadap barang impor yang dilarang dan/atau pembatasan, bukan mengenai penghapusan atau pencabutan mengenai barang impor harus dalam keadaan baru sebagaimana diamanatkan dalam UU Perdagangan. Hal ini, jika pengeculian disetujui Menteri, baru dapat dilaksanakan, jika tidak disetujui maka akan tetap sesuai dengan peraturan yang diatur, oleh karena itu Peneliti tidak sependapat dengan pendapat yang diberikan bahwa PERMENKEU No. 6/PMK.010/PER/2017 sudah harmonis dan sinkron dengan uu perdagangan, PERMENDAG No. 48/M-DAG/PER/7/2015 dan PERMENDAG No. 51/MDAG/PER/7/2015.

Faktor penyebab terjadinya perbedaan pengaturan terhadap barang impor dalam keadaan baru adalah dari latar belakang dibentuk peraturan perundangundangan yaitu UU Perdagangan, PERMENDAG No. 48/M-DAG/PER/7/2015, PERMENDAG No. 51/M-DAG/PER/7/2015, dan PERMENKEU No. 6/PMK.010/PER/2017, dan teori sistem hukum tidak diterapkan karena dalam sebuah sistem hukum adanya tahapan pembentukan peraturan perundangundangan yang salah satunya berupa harmonisasi dan sinkronisasi antara Pancasila, UUD NRI Tahun 1945, dan peraturan perundang-undangan. Hukum itu sah apabila bersumber dan berdasar pada norma yang dibentuk oleh norma yang lebih tinggi, dalam hal ini asas lex superiori derogate legi inferiori. Tidak seharusnya terjadi perbedaan pengaturan terhadap barang impor dalam keadaan baru, karena dapat merugikan masyarakat dan pelaku bisnis baik langsung maupun tidak langsung. Peraturan perundang-undangan merupakan perangkat hukum yang berfungsi memberikan suatu kepastian hukum terutama dalam kegiatan berbisnis dengan tujuan meningkatkan perekonomian nasional dan kesejahteraan masyarakat. 


\section{Upaya Untuk Mengharmoniskan dan Menyinkronkan Perbedaan Pengaturan Barang Impor dalam Keadaan Baru}

Adanya perbedaan pengaturan barang impor dalam keadaan baru, maka diperlukan upaya untuk mengharmoniskan dan menyinkronkan terhadap perbedaan pengaturan tersebut. Seiring dengan perkembangan hukum untuk mengakomodasi kepentingan negara modern, masyarakat juga menginginkan fungsi hukum yang dapat menjamin kepastian dan kegunaan dalam hubungan mereka satu sama lain. Dengan demikian maka nilai dasar dari hukum adalah sebagaimana telah diintrodusir oleh Gustav Radbruch, yaitu keadilan, kegunaan dan kepastian. ${ }^{12}$ Peraturan perundang-undangan harus dibentuk oleh lembaga berwenang. Pembentuk perundang-undangan harus memperhatikan sumber dan tingkatan yang diatur dalam hierarki Pasal 7 Undang-Undang Nomor 11 Tahun 2012 tentang Pembentuk Peraturan Perundang-undangan (selanjutnya ditulis UU pembentukan peraturan perundang-undangan), melakukan tahap-tahap pembuatan atau pembentukan yang diatur dalam UU pembentuk peraturan perundang-undangan dari perencanaan, penyusunan, pembahasan, pengesahan atau penetapan, dan pengundangan serta melakukan harmonisasi dan sinkronisasi oleh DJPP. Peraturan perundang-undangan merupakan suatu kaidah hukum yang secara struktur dan sistematika tersusun dengan memberikan suatu kepastian hukum dengan tujuan menjamin perlindungan hak dan kewajiban segenap masyarakat Indonesia.

Upaya untuk mengharmoniskan dan menyinkronkan perbedaan pengaturan barang impor dalam keadaan baru terhadap UU Perdagangan, PERMENDAG No. 48/M-DAG/PER/7/2015, dan PERMENDAG No. 51/M-DAG/PER/7/2015 dengan PERMENKEU No. 6/PMK.010/2017 yaitu memperhatikan prosedur pembentukan peraturan perundang-undangan terhadap tahapan harmonisasi dan sinkronisasi yang harus dilakukan oleh DJPP. Pada teori sistem hukum sebagaimana tidak menghendaki adanya konflik maka cara mengatasi konflik tersebut maka diperlukan adanya suatu ketentuan umum yang pelaksanaannya itu konsisten dan jika terjadi konflik akan berlaku secara konsisten asas-asas lex

12 Muhammad Muhtarom, "Harmonisasi Dan Sinkronisasi Peraturan Hukum Perkoperasian Dan Lembaga Keuangan Mikro”, Yustisia, Vol. 3 No.2, Mei-Agustus 2014, hlm. 56. 
specialis derogat legi generali, lex posteriori derogat legi priori, atau lex superiori derogat legi inferiori. Tahapan teori sistem hukum ini dituangkan dalam pembetukan peraturan perundang-undangan berupa hierarki Pasal 7 UU Pembentukan Peraturan Perundang-undangan. Kementerian Hukum dan Hak Asasi Manusia merupakan salah satu kementerian pelaksana tugas-tugas pemerintahan (bestuurer) yang dibentuk guna membantu tugas-tugas Presiden (eksekutif), baik sebagai kepala negara maupun kepala pemerintahan, dalam permasalahan-permasalahan yang menyangkut pelaksanaan tugas dibidang pembangunan sistem hukum nasional. Tugas di bidang hukum merupakan peran yang strategis dalam rangka mengaktualisasikan fungsi hukum, menegakkan hukum, menciptakan budaya hukum, dan membentuk peraturan perundang-undangan yang adil, konsisten, tidak diskriminstif, serta memperhatikan hak asasi manusia. Dalam kerangka mewujudkan sistem hukum nasional tentunya harus memperhatikan sinkronisasi dan harmonisasi peraturan perundangan-undangan yang berlaku, baik dalam garis vertikal maupun horizontal. ${ }^{13}$

Peraturan Menteri Hukum Dan Hak Asasi Manusia Nomor 30 Tahun 2015 tentang Tata Cara Pembentukan Peraturan Menteri Di Lingkungan Kementerian Hukum dan Hak Asasi Manusia (selanjutnya ditulis PERMENKUMHAM No. 30 Tahun 2015), sebagaimana dengan tujuan meningkatkan tertib administrasi dan menciptakan keseragaman dalam pembentukan peraturan menteri serta kelancaran proses penyusunan rancangan peraturan menteri. Pembentukan peraturan menteri adalah pembuatan peraturan menteri yang mencakup tahapan perencanaan, penyusunan, penetapan, dan pengundangan. Pasal 3 PERMENKUMHAM No. 30 Tahun 2015, perencanaan penyusunan peraturan menteri disusun berdasarkan perintah peraturan perundang-undangan yang lebih tinggi atau berdasarkan kewenangan.

Penyusunan rancangan peraturan menteri dilakukan oleh pemrakarsa. Dalam penyusunan rancangan peraturan menteri, pemrakarsa dapat membentuk tim penyusunan rancangan peraturan menteri. Tim penyusunan terdiri atas unsur

13 Taufik H Simatupang, "Peran Perancang Peraturan Perundang-Undangan Kantor Wilayah Kementerian Hukum Dan Hak Asasi Manusia Dalam Rangka Harmonisasi Peraturan Daerah", JIKH, Vol. 11 No. 1, Maret 2017, hlm. 13-14. 
Pemrakarsa, unit eselon I terkait, DJPP, Biro Perencanaan, dan Perancang Peraturan Perundang-undangan. Pasal 12 PERMENKUMHAM No. 30 Tahun 2015, penyampaian hasil penyusunan, Sekretaris Jenderal melalui Kepala Biro Perencanaan menyampaikan hasil penyusunan rancangan peraturan menteri kepada DJPP untuk dilakukan penyelarasan rancangan peraturan menteri dalam waktu paling lama 7 hari kerja. Dalam melakukan penyelarasan rancangan peraturan menteri, DJPP melibatkan wakil dari Pemrakarsa, Biro Perencanaan, dan/atau unit terkait. Penyelarasan rancangan peraturan menteri dimaksudkan untuk menyelaraskan rancangan peraturan menteri dengan peraturan perundangundangan yang lebih tinggi dan teknik penyusunan peraturan perundangundangan serta menghasilkan kesepakatan terhadap subtansi yang diatur dalam Rancangan Peraturan Menteri. Sinkronisasi peraturan perundang-undangan selain memperhatikan susunan hierarki peraturan perundang-undangan (sinkronisasi terhadap sistematika hukum) juga memperhatikan tentang asas dan norma yang terkandung dalam peraturan perundang-undangan. ${ }^{14}$

Pasal 14 PERMENKUMHAM No. 30 Tahun 2015, DJPP menyampaikan rancangan peraturan menteri yang telah disepakati dalam rapat penyelarasan kepada Pemrakarsa dan Sekretaris Jenderal. Setelah itu, Sekretaris Jenderal menyampaikan rancangan peraturan menteri yang telah mendapatkan paraf persetujuan untuk memperoleh penetapan Menteri dalam waktu paling lama 2 hari terhitung sejak rancangan peraturan menteri yang telah mendapat paraf persetujuan diterima. Rancangan peraturan menteri ditetapkan oleh menteri menjadi peraturan menteri dengan membubuhkan tanda tangan. Sekretaris Jenderal membubuhkan nomor dan tahun pada naskah asli peraturan menteri yang telah mendapatkan penetapan. Naskah asli disampaikan kepada DJPP untuk diundangkan dalam Berita Negara Republik Indonesia dan/atau Tambahan Berita Negara Republik Indonesia. Ketentuan mengenai tata cara pengundangan peraturan menteri dilaksanakan sesuai dengan ketentuan peraturan perundangundangan, maka dari itu setiap pembuat Peraturan Menteri harus mengacu kepada

\footnotetext{
14 Shandra Lisya Wandasari, "Sinkronisasi Peraturan Perundang-Undangan Dalam Mewujudkan Pengurangan Risiko Bencana”, Unnes Law Journal, Vol. 2, Februari 2013, hlm. 146-147.
} 
PERMENKUMHAM No. 30 Tahun 2015 agar terjadinya harmonisasi dan sinkronisasi.

Merujuk pada asas-asas pembentukan peraturan perundang-undangan adalah suatu pedoman atau suatu rambu-rambu dalam pembentukan peraturan perundang-undangan yang baik. Dalam bidang hukum yang menyangkut pembentukan peraturan perundang-undangan negara, menurut pendapat Burkhardat Krems menyebutkannya dengan istilah staatsliche rechtssetzung, sehingga pembentuka peraturan ini menyangkut:15 1 . isi peraturan (inhalt der regelug); 2. bentuk dan susunan peraturan (form der regelung); 3 . metode pembentukan peraturan (method der ausarbeitung der regelung); dan 4. prosedur dan proses pembentukan peraturan (verfahren der ausarbeitung der regelung).

Asas bagi pembentukan peraturan perundang-undangan negara akan meliputi asas-asas hukum yang berkaitan dengan itu. A.Hamid S. Attami memberikan pendapat bahwa pembentukan peraturan perundang-undangan Indonesia yang patut yaitu cita hukum Indonesia dan norma fundamental negara yaitu Pancasila, asas negara berdasar atas hukum dan asas pemerintahan berdasarkan sistem konstitusi, serta asas-asas lainnya. ${ }^{16}$ Pembentukan peraturan perundang-undangan hampir sama yang dikemukan oleh Burkhadat Krems dan A. Hamid S. Attami berupa norma fundamental negara yaitu Pancasila dan asasasas pembentukan peraturan perundang-undangan.

Pasal 5 UU Pembentukan Peraturan Perundang-undangan harus dilakukan berdasarkan pada asas pembentukan peraturan perundang-undangan yang baik, yang meliputi kejelasan tujuan, kelembagaan atau pejabat pembentuk yang tepat, kesesuaian antara jenis, hierarki, dan materi muatan, dapat dilaksanakan, kedayagunaan dan kehasilgunaan, kejelasan rumusan, dan keterbukaan. Pembentukan peraturan perundang-undangan yang berlaku saat ini terdapat kecenderungan untuk meletakan asas-asas hukum atau asas-asas pembentukan peraturan perundang-undangan tersebut di dalam salah satu pasal-pasal awal, atau dalam bab ketentuan umum, seperti dirumuskan dalam uu pembentukan

${ }^{15}$ Maria Farida Indrati, Ilmu Perundang-Undangan - Jenis, Fungsi, dan Materi Muatan, Kanisius, Yogyakarta, 2007, hlm. 252.

16 Ibid., hlm. 254-255. 
peraturan perundang-undangan. Jika membentuk peraturan perundangundangan harus berpedoman terhadap asas-asas hukum karena merupakan rambu-rambu pembangunan hukum Nasional Rebublik Indonesia. Dengan adanya asas hukum maka mempunyai akibat suatu sanksi dengan tujuan aturan hukum yang dibuat tidak dilanggar dan mempunyai batasan.

Kuntjoro Purbopranoto memberikan pendapat bahwa asas-asas harus disesuaikan dengan dasar falsafah negara Republik Indonesia yakni Pancasila dan UUD 1945. Asas-asas umum pemerintahan yang baik terdiri dari asas kepastian hukum, asas keseimbangan, dan asas kesamaan dalam mengambil keputusan. ${ }^{17}$ Peraturan perundang-undangan yang baik, menurut pendapat Bagir Manan, suatu peraturan perundang-undangan yang baik setidaknya didasari pada 3, yaitu: ${ }^{18}$

1. Dasar Yuridis (juridishe gelding), yaitu pertama, keharusan adanya kewenangan dari pembuat peraturan perundang-undangan. Setiap peraturan perundangundangan harus dibuat oleh badan atau pejabat yang berwenang. Kalau tidak, peraturan perundang-undangan itu batal demi hukum (van rechtwegenietig) serta dianggap tidak pernah ada dan segala akibat batal secara hukum. Kedua, keharusan adanya kesesuaian bentuk atau jenis peraturan perundang-undangan dengan materi yang diatur, terutama kalau diperintahkan oleh peraturan perundang-undangan tingkat lebih tinggi atau sederajat. Ketidaksesuaian bentuk ini dapat menjadi alasan untuk membatalkan peraturan perundangundangan tersebut. Ketiga, keharusan mengikuti tata cara tertentu. Apabila tata cara tersebut tidak diikuti, peraturan perundang-undangan mungkin batal demi hukum atau tidak/belum mempunyai kekuatan hukum mengikat. Dalam Undang-Undang tentang pengundangan (pengumuman) bahwa setiap UndangUndang harus diundangkan dalam Lembaran Negara sebagai satu-satunya cara untuk mempunyai kekuatan mengikat. Keempat, keharusan tidak bertentangan dengan peraturan perundang-undangan yang lebih tinggi tingkatannya. Suatu Undang-Undang tidak boleh mengandung kaidah yang bertentangan dengan UUD 1945. Demikian pula seterusnya sampai pada peraturan perundangundangan tingkat lebih bawah.

2. Dasar sosiologis (sociologische gelding), yaitu mencerminkan kenyataan yang hidup dalam masyarakat.

3. Dasar filosofis, bahwa setiap masyarakat selalu mempunyai cita hukum (rechtsidee) yaitu apa yang mereka harapkan dari hukum, misalnya untuk menjamin keadilan, ketertiban, kesejahteraan, dan sebagainya.

Dengan demikian, upaya untuk mengharmoniskan dan menyinkronkan perbedaan pengaturan barang impor dalam keadaan baru adalah memperhatikan

\footnotetext{
${ }_{17}$ Muhsan, Pengantar Hukum Administrasi Negara Indonesia, Liberty, Yogyakarta, 1982, hlm. 74-75.

18 Bagir Manan, Dasar-Dasar Perundang-undangan Indonesia, Ind-Hill. Co., Jakarta, 1992, hlm. 13-18.
} 
prosedur pembentukan peraturan perundang-undangan (Undang-Undang Nomor 11 Tahun 2012 tentang Pembentuk Peraturan Perundang-undanga) terhadap tahapan harmonisasi dan sinkronisasi (Peraturan Menteri Hukum Dan Hak Asasi Manusia Nomor 30 Tahun 2015 tentang Tata Cara Pembentukan Peraturan Menteri Di Lingkungan Kementerian Hukum dan Hak Asasi Manusia) yang harus dilakukan oleh Dirjen Jenderal Pembentukan Peraturan Perundang-undangan (DJPP). Harmonisasi dan sinkronisasi merupakan hal yang penting karena dapat berdampak kesetiap peraturan perundang-undangan sehingga, setiap peraturan perundang-undangan sebelum diundangkan wajib melalui proses di DJPP agar peraturan tidak bertabrakan dan berbenturan.

\section{Penutup}

Berdasarkan permasalahan yang telah dikemukakan dan setelah diadakan pengolahan serta analisis data yang diperoleh dari hasil penelitian berupa, pertama, faktor Penyebab Terjadinya Perbedaan Pengaturan Barang Impor Dalam Keadaan Baru adalah dari latar belakang dibentuk peraturan perundang-undangan yaitu UU Perdagangan, PERMENDAG No. 48/M-DAG/PER/7/2015, PERMENDAG No. 51/M-DAG/PER/7/2015, dan PERMENKEU No. 6/PMK.010/PER/2017 dan teori sistem hukum tidak diterapkan karena dalam sebuah sistem hukum adanya tahapan pembentukan peraturan perundang-undangan yang salah satunya berupa harmonisasi dan sinkronisasi antara Pancasila, UUD 1945, dan peraturan perundang-undangan. Hukum itu sah apabila bersumber dan berdasar pada norma yang dibentuk oleh norma yang lebih tinggi, dalam hal ini asas lex superiori derogate legi inferiori.

Kedua, upaya untuk mengharmoniskan dan menyinkronkan perbedaan pengaturan barang impor dalam keadaan baru adalah memperhatikan prosedur pembentukan peraturan perundang-undangan terhadap tahapan harmonisasi dan sinkronisasi yang harus dilakukan oleh Direktorat Jenderal Peraturan Perundangan (DJPP).

Oleh karena itu, perlu dilakukan upaya harmonisasi dan sinkronisasi dengan berpedoman pada sistem hukum yang ada dengan mencermati setiap aturan hukum yang berhubungan dengan aturan hukum yang akan dibentuk, melakukan 
tahap-tahap yang diamanatkan oleh UU pembentuk peraturan perundangundangan. Selain itu, juga dibutuhkan suatu sistem database karena jika ada suatu undang-undang ataupun peraturan menteri yang berbenturan, dapat diketahui langsung (terlacak) sebelum aturan hukum tersebut diundangkan dan disahkan.

\section{Daftar Pustaka}

Buku

Departemen Pendidikan Nasional, Kamus Besar Bahasa Indonesia, Edisi Keempat, Gramedia Pustaka Utama, Jakarta, 2012.

Indrati, Maria Farida, Ilmu Perundang-Undangan - Jenis, Fungsi, dan Materi Muatan, Kanisius, Yogyakarta, 2007.

Manan, Bagir, Dasar-Dasar Perundang-undangan Indonesia, Ind-Hill. Co., Jakarta, 1992.

Marzuki, Peter Mahmud, Penelitian Hukum, Prenada Media Group, Jakarta, 2016.

Muhsan, Pengantar Hukum Administrasi Negara Indonesia, Liberty, Yogyakarta, 1982

Raja, Maringan Lumban, Faktor-faktor Yang Mempengaruhi Eksportir dan Importir dalam Perdagangan Luar Negeri (International Sale of Goods)., Universitas Diponogoro, Semarang, 1998.

Suratman dan H. Philips Dillah, Metode Penelitian Hukum, Alfabeta, Bandung, 2013.

\section{Jurnal}

Asmorowati, Meiti, "Pembebasan Bea Masuk Atas Impor Buku Ilmu Pengetahuan Berdasarkan Pasal 25 UU No. 17 Tahun 2006 Jo Skmenkeu No. 103/Kmk.04/2007", Jurnal Wawasan Hukum, Vol. 26 No. 01, Februari 2012.

Djalali, Nur Rahmi, "Perlindungan Hukum Industri Garmen Dalam Negeri, Terhadap Impor Pakaian Bekas", Jurnal Ilmu Hukum Legal Opinion Edisi 2, Volume 3, 2015.

Muhtarom, Muhammad, "Harmonisasi Dan Sinkronisasi Peraturan Hukum Perkoperasian Dan Lembaga Keuangan Mikro", Yustisia, Vol. 3 No.2, MeiAgustus 2014.

Simatupang, Taufik H, "Peran Perancang Peraturan Perundang-Undangan Kantor Wilayah Kementerian Hukum Dan Hak Asasi Manusia Dalam Rangka Harmonisasi Peraturan Daerah", JIKH, Vol. 11 No. 1, Maret 2017.

Wandasari, Shandra Lisya, "Sinkronisasi Peraturan Perundang-Undangan Dalam Mewujudkan Pengurangan Risiko Bencana", Unnes Law Journal, Vol. 2, Februari 2013.

\section{Peraturan Perundang-undangan}

Peraturan Menteri Hukum Dan Hak Asasi Manusia Nomor 30 Tahun 2015 tentang Tata Cara Pembentukan Peraturan Menteri Di Lingkungan Kementerian Hukum Dan Hak Asasi Manusia 
Peraturan Menteri Keuangan Nomor 6/PMK.010/2017 tentang Penetapan Klasifikasi Barang dan Pembebanan Tarif Bea Masuk Atas Barang Impor.

Peraturan Menteri Perdagangan Nomor 48/M-DAG/PER/7/2015 tentang Ketentuan Umum Bidang Impor.

Peraturan Menteri Perdagangan Nomor 51/M-DAG/PER/7/2015 tentang Larangan Impor Pakaian Bekas.

Undang-Undang Dasar Republik Indonesia 1945.

Undang-Undang Nomor 10 Tahun 1995 tentang Kepabeanan, Lembaran Negara Republik Indonesia Nomor 75 Tahun 1995, Tambahan Lembaran Negara Republik Indonesia Nomor 3612.

Undang-Undang Nomor 12 Tahun 2011 tentang Pembentukan Peraturan Perundang-Undangan, Lembaran Negara Republik Indonesia Nomor 82 Tahun 2011, Tambahan Lembaran Negara Nomor 5234.

Undang-Undang Nomor 7 Tahun 2014 tentang Perdagangan, Lembaran Negara Republik Indonesia Nomor 45 Tahun 2015, Tambahan Lembaran Negara Nomor 5512.

\section{Internet}

"Tentang INSW" http://bctemas.beacukai.go.id/faq/tentang-insw/, diakses pada tanggal 30 November 2017

“Definisi \& Manfaat" http:/ /djpen.kemendag.go.id/app_frontend/contents/147definisi-manfaat, diakses tanggal 26 September 2017

"Larangan Impor Baju Bekas Dihapus, Tarif Bea Masuk Jadi Pengganti" http:/ / bisnis.liputan6.com/read/2280474/larangan-impor-baju-bekasdihapus-tarif-bea-masuk-jadi-pengganti, di akses pada tanggal 16 November 2016

"Impor Baju Bekas Dilarang Namun Masih Kena Bea Masuk 35\%" http:/ / www.cnnindonesia.com/ekonomi/20150727140602-7868349/impor-baju-bekas-dilarang-namun-masih-kena-bea-masuk-35/, di akses pada tanggal 16 November 2016

"Minimnya Database Peraturan, Mempersulit Harmonisasi Hukum" http:/ / www.hukumonline.com/berita/baca/lt4d0989a80b9af/minimnya -idatabasei-peraturan-persulit-harmonisasi-hukum, diakses pada tanggal 11 September 2017.

“Tentang INSW" http://bctemas.beacukai.go.id/faq/tentang-insw/, diakses pada tanggal 30 November 2017. 